\title{
FAKTOR-FAKTOR YANG BERHUBUNGAN DENGAN PENGETAHUAN PERAWAT TENTANG PENATALAKSANAAN ASUHAN KEPERAWATAN PASIEN DEKOMPENSASI KORDIS DI RUANG ICVCU RSUD Dr.MOEWARDI
}

\author{
Widodo \\ Politeknik Kesehatan Surakarta Jurusan Keperawatan
}

\begin{abstract}
Knowledge, Management, Nursing Care Application Of Cardiac Decompensation. This study is a non-experimental quantitative research using correlation descriptive method. Research subjects are nurses who provide nursing care in patients with cardiac decompensation. There are 22 people as respondents. the form of data collection is using questionnaire. The Data analysis techniques using the Rank Spearman.The results show the value of the bivariate analysis Rank Spearman formula that there is no correlation between nurse's age with the nurse's knowledge about the management of the nursing care of patients with cardiac decompensation, shown as calculated values of $r_{\text {count }}<r_{\text {table }}(0,082<.428)$. there is no correlation between level of a nurse's knowledge education about management of the nursing care of patient with cardiac decompensation shown as calculated values of $r_{\text {count }}<r_{\text {table }}(0.290<0.428)$, there is no correlation between the long time of nurse working with the nurse's knowledge about the management of nursing care of patients with cardiac decompentation, shown as the value of $r_{\text {count }}<r_{\text {table }}(0.245<0.428)$, and there is a correlation between training program with the knowledge of nurse on the management of the of the patients nursing care with cardiac decompensation which is counted $r_{\text {count }}$ $<r_{\text {table }}(0.542>0.428)$. There is a correlation between training factor with the nurses knowledge about nursing care management of patients with cardiac decompensation
\end{abstract}

Keywords : Knowledge, Management, Nursing Care Application Of Cardiac Decompensation.

Abstak : Pengetahuan, Penatalaksanaan, Asuhan Keperawatan Dekompensasi Kordis. Tujuan penilitian ini adalah Mengetahui faktor-faktor yang berhubungan dengan pengetahuan perawat tentang penatalaksanaan asuhan keperawatan pasien Dekompensasi Kordis di ruang ICVCU RSUD Dr. Moewardi Surakarta. Penelitian ini merupakan penelitian kuantitatif non eksperimental menggunakan metode deskriptif koleratif. Subjek penelitian adalah perawat pelaksana yang memberikan asuhan keperawatan pada pasien dekompensasi kordis sebanyak 22 orang Pengumpulan data berupa kuesioner. Teknik analisis data dengan menggunakan Rank Spearman. Hasil penelitian menunjukkan nilai analisis bivariat rumus Rank Spearman bahwa tidak ada hubungan antara umur dengan pengetahuan perawat tentang penatalaksanaan asuhan keperawatan pasien dekompensasi kordis dengan nilai $r$ hitung $<\mathrm{r}$ tabel $(0,082<$ 0,428 ), tidak ada hubungan antara tingkat pendidikan dengan pengetahuan perawat tentang penatalaksanaan asuhan keperawatan pasien dekompensasi kordis dengan nilai $r$ hitung $<\mathrm{r}$ tabel $(0,290<0,428)$, tidak ada hubungan antara lama kerja dengan 
pengetahuan perawat tentang penatalaksanaan asuhan keperawatan pasien dekompensasi kordis dengan $\mathrm{r}$ hitung $<\mathrm{r}$ tabel $(0,254<0,428)$, dan ada hubungan antara pelatihan dengan pengetahuan perawat tentang penatalaksanaan asuhan keperawatan pasien dekompensasi kordis dengan $r$ hitung $>r$ table $(0,542>0,428)$. Ada hubungan antara faktor pelatihan dengan pengetahuan perawat tentang penatalaksanaan asuhan keperawatan pasien dekompensasi kordis

Kata Kunci : Pengetahuan, Penatalaksanaan, Asuhan Keperawatan Dekompensasi Kordis,

\section{PENDAHULUAN}

Prevalensi penyakit jantung di Indonesia dari tahun ke tahun terus meningkat berdasarkan data RS Jantung Harapan Kita, peningkatan kasus dimulai pada tahun 1997 dengan 248 kasus, kemudian melaju dengan pesat hingga mencapai puncak tahun 2000 dengan 532 kasus. Kematian akibat penyakit jantung tahun 2000 hanya 4,3\% jumlah yang lebih kecil dibandingkan dengan insiden pada tahun 1999 sejumlah 12,2\% (Hidayati, 2001). Tahun 2006 kasus gagal jantung di rawat inap dan rawat jalan Rumah Sakit Cipto Mangunkusumo Jakarta terdapat $3,32 \%$ dari total 11.711 pasien (Rahmawati, 2007). Sedangkan berdasarkan survey yang dilakukan penulis di Ruang ICCU RSUD Dr. Moewardi Surakarta, jumlah penderita dekompensasi kordis tahun 2008 ada 50 orang.

Pengetahuan yang tinggi akan menimbulkan seseorang lebih mampu dan bersedia menerima tanggung jawab (Gibson dkk, 1996), dengan pengetahuan yang tinggi penatalaksanaan pada pasien dekompensasi kordis akan dilakukan dengan benar sesuai prosedur yang telah di tetapkan dan penuh tanggung jawab sehingga mengurangi angka kematian pasien dekompensasi kordis yang setiap tahunnya meningkat. Penatalaksanaan untuk mengurangi angka kematian karena penyakit gagal jantung kongestif adalah menurunkan kerja jantung, untuk meningkatkan curah jantung dan kontraktilitas miokard dan untuk menurunkan retensi garam dan air (Hudak dan Gallo, 1997). Tirah baring merupakan salah satu cara untuk menurunkan aktifitas seluruh kebutuhan kerja jantung, volume intravaskuler melalui induksi deuresis berbaring (Hudak \& Gallo, 2002). Tujuan dari penelitian ini adalah Mengetahui faktor-faktor yang berhubungan dengan pengetahuan perawat tentang penatalaksanaan asuhan keperawatan pasien Dekompensasi Kordis di ruang ICVCU RSUD Dr. Moewardi Surakarta

\section{METODE PENELITIAN}

Jenis penelitian adalah penelitian kuantitatif, non eksperimental metode yang digunakan adalah deskriptif korelational dengan pendekatan Crossectional. Rancangan penelitian ini adalah deskriptif korelasi yaitu rancangan penelitian dengan maksud untuk menggambarkan hubungan pengetahuan, umur, pendidikan, pelatihan dan lama kerja dengan penatalaksanaan pasien Dekompensasi Kordis.

\section{HASIL PENELITIAN \\ A. Analisa Univariat}

Karakteristik responden dengan berdasarkan umur, pendidikan, lama kerja, 
pelatihan, dan pengetahuan perawat tentang penatalaksanaan asuhan keperawatan pada pasien Dekompensasi Kordis sebagai berikut:

1. Karakteristik
berdasarkan umur

\section{Tabel 1}

Distribusi Frekuensi Umur Responden

\begin{tabular}{|c|c|c|c|}
\hline No. & Umur & Jumlah & $\begin{array}{c}\text { Persentase } \\
(\%)\end{array}$ \\
\hline 1. & $\begin{array}{c}21-35 \\
\text { tahun }\end{array}$ & 13 & 59,1 \\
\hline 2. & $\begin{array}{l}36-45 \\
\text { tahun }\end{array}$ & 7 & 31,8 \\
\hline 3. & $>46$ tahun & 2 & 9,1 \\
\hline & Total & 22 & 100 \\
\hline
\end{tabular}
responden yang diteliti terdapat 13 responden $(59,1 \%)$ yang berumur $21-35$ tahun, 7 responden $(31,8 \%)$ yang berumur 36 - 45 tahun dan 2 responden $(9,1 \%)$ yang berumur $>46$ tahun.

2. Karakteristik responden berdasarkan tingkat pendidikan

\section{Tabel 2}

Distribusi Frekuensi Tingkat Pendidikan Responden

\begin{tabular}{|c|c|c|c|}
\hline No & $\begin{array}{l}\text { Tingkat } \\
\text { Pendidikan }\end{array}$ & Jumlah & $\begin{array}{c}\text { Persentase } \\
(\%)\end{array}$ \\
\hline 1. & SPK & 2 & 9,1 \\
\hline 2. & D3 Keperawatan & 15 & 68,2 \\
\hline 3. & S1 Keperawatan & 5 & 22,7 \\
\hline & Total & 22 & 100 \\
\hline
\end{tabular}
responden yang diteliti terdapat 2 responden $(9,1 \%)$ berpendidikan SPK, 15 responden $(68,2 \%)$ yang berpendidikan D3 Keperawatan dan 5 responden $(22,7 \%)$ yang 5 di bawah ini:

3. Karakteristik berdasarkan lama kerja
Tabel 3

Distribusi Frekuensi Lama Kerja Responden

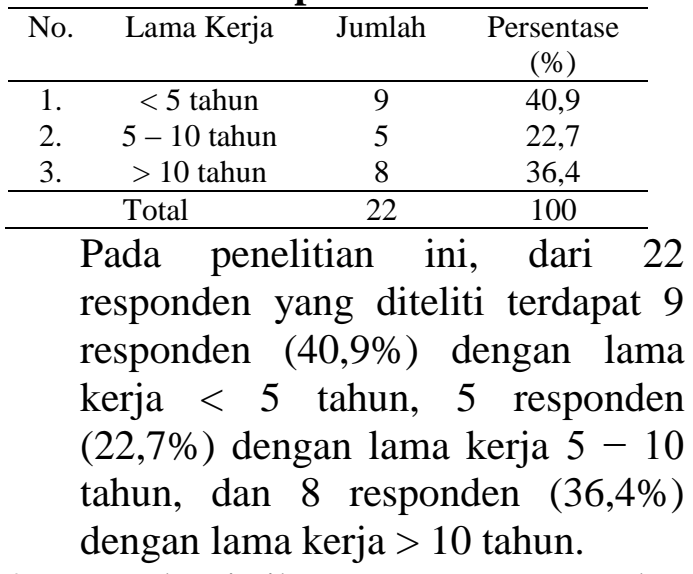

4. Karakteristik responden berdasarkan Pelatihan

Tabel 4

Distribusi Frekuensi Pelatihan Responden

\begin{tabular}{|c|c|c|c|}
\hline No. & Pelatihan & Jumlah & $\begin{array}{c}\text { Persentase } \\
(\%)\end{array}$ \\
\hline 1. & 0 kali & 5 & 22,7 \\
\hline 2. & $1-2$ kali & 12 & 54,5 \\
\hline 3. & $3-4$ kali & 5 & 22,7 \\
\hline & Total & 22 & 100 \\
\hline
\end{tabular}
responden yang diteliti terdapat 5 responden $(22,7 \%)$ dengan pelatihan 0 kali, 12 responden $(54,5 \%)$ dengan pelatihan 1 - 2 kali, dan 5 responden $(22,7 \%)$ dengan pelatihan 3 - 4 kali.
5. Karakteristik responden berdasarkan Pengetahuan

Tabel 5

Distribusi Frekuensi Pengetahuan Responden

\begin{tabular}{clcc}
\hline No. & Pengetahuan & Jumlah & $\begin{array}{c}\text { Persentase } \\
(\%)\end{array}$ \\
\hline 1. & $\begin{array}{l}\text { Baik (75\% - } \\
100 \%)\end{array}$ & 10 & 45,5 \\
2. & $\begin{array}{l}\text { Cukup }(50 \%- \\
75 \%)\end{array}$ & 12 & 54,5 \\
3. & Kurang $(<50 \%)$ & 0 & 0 \\
\hline & Total & 22 & 100 \\
\hline
\end{tabular}


Pada penelitian ini, dari 22 responden yang diteliti terdapat 12 responden $(54,5 \%)$ memiliki pengetahuan cukup, 10 responden $(45,5 \%)$ dengan pengetahuan baik dan tidak ada responden yang memiliki pengetahuan kurang.

Hubungan antara umur dengan pengetahuan perawat tentang penatalaksanaan asuhan keperawatan pasien Dekompensasi Kordis.

Hasil analisis hubungan antara umur dengan pengetahuan perawat tentang penatalaksanaan asuhan keperawatan pasien Dekompensasi Kordis menggunakan uji non parametrik Rank Spearmant dengan bantuan SPSS for windows versi 15.0 diperoleh hasil sebagai berikut:

\section{Tabel 6}

Hasil Uji Korelasi Umur dengan Pengetahuan

\begin{tabular}{ccc}
\hline Variabel & r hitung & r table \\
\hline $\begin{array}{c}\text { Umur } * \\
\text { Pengetahuan }\end{array}$ & 0,082 & 0,428 \\
\hline Berdasarkan & tabel & di $\quad$ atas,
\end{tabular}
diperoleh perbandingan nilai $r$ hitung Rank Spearman sebesar 0,082, nilai $r$ tabel dengan $\mathrm{N}=22$ dan taraf signifikan 0,05 sebesar 0,428 . Karena $r$ hitung $<\mathrm{r}$ tabel $(0,082<0,428)$ maka hipotesis Ho diterima dan Ha ditolak. Hal ini menunjukkan bahwa tidak ada hubungan antara umur dengan pengetahuan perawat tentang penatalaksanaan asuhan keperawatan pasien Dekompensasi Kordis di ruang ICVCU RSUD Dr. Moewardi Surakarta Tahun 2011.

Hasil analisis hubungan antara tingkat pendidikan dengan pengetahuan perawat tentang penatalaksanaan asuhan keperawatan pasien Dekompensasi Kordis di ruang ICVCU RSUD Dr. Moewardi Surakarta Tahun 2011 adalah sangat rendah menggunakan uji non parametrik Rank Spearmant diperoleh hasil sebagai berikut:

\section{PEMBAHASAN}

1. Karakteristik responden

Karakteristik umur responden, dari 22 responden yang diteliti terdapat 13 responden $(59,1 \%)$ yang berumur $21-35$ tahun, 7 responden $(31,8 \%)$ yang berumur 36 - 45 tahun dan 2 responden $(9,1 \%)$ yang berumur $>46$ tahun. Umur antara 21 -35 tahun merupakan usia yang produktif, maka distribusi tenaga perawat di ruang ICVCU merupakan usia yang produktif. Menurut Purwanto (2005) bahwa saat yang paling produktif dalam masa hidup seseorang untuk mencapai puncak karirnya berbeda - beda tergantung jenis pekerjaan dan individu yang bersangkutan. Pekerjaan - pekerjaan yang membutuhkan kekuatan, kecepatan dan kecermatan gerak usia yang paling efektif adalah sekitar 25 - 29 tahun.

Karakteristik tingkat pendidikan responden, dari 22 responden yang diteliti terdapat 2 responden $(9,1 \%)$ berpendidikan SPK, 15 responden $(68,2 \%)$ yang berpendidikan D3 Keperawatan dan 5 responden $(22,7 \%)$ yang berpendidikan S1 Keperawatan. Dilihat dari latar belakang pendidikan, responden mempunyai tingkat pendidikan yang cukup tinggi, di mana responden berpendidikan SPK, D3 dan S1 Keperawatan. Berdasarkan tabel 8 di atas, dapat diketahui bahwa mayoritas responden memiliki tingkat pendidikan Diploma 3 Keperawatan (68,2\%). Menurut Nurachmah (2000) bahwa untuk menjadi perawat professional pemula adalah lulusan Diploma 3 Keperawatan, sedangkan perawat professional harus Sarjana (Ners) mereka yang lulusan 
Diploma 3 secara keilmuan sudah mendapatkan cukup bekal untuk memberikan Asuhan Keperawatan pada pasien. Disamping pendidikan formal yang dimiliki setiap perawat juga mendapatkan pelatihan guna meningkatkan keterampilan perawat. Sedangkan menurut Grossman (1999), pendidikan merupakan salah satu KDM yang diperlukan untuk pengembangan diri. Semakin tinggi tingkat pendidikan, semakin mudah mereka menerima serta pengembangkan pengetahuan dan teknologi, sehingga akan meningkatkan produktifitas yang pada akhirnya akan meningkatkan kesejahteraan keluarga.

Karakteristik lama kerja responden, dari 22 responden yang diteliti terdapat 9 responden $(40,9 \%)$ dengan lama kerja $<5$ tahun, 5 responden $(22,7 \%)$ dengan lama kerja 5-10 tahun, dan 8 responden $(36,4 \%)$ dengan lama kerja > 10 tahun. sebagian besar $(40,9 \%)$ responden memilki lama kerja $<5$ tahun. Menurut Gibson, dkk (1997), masa kerja seseorang akan menentukan prestasi individu yang merupakan dasar prestasi dan kinerja organisasi. Semakin lama seseorang bekerja di suatu organisasi, maka tingkat prestasi individu akan semakin meningkat yang dibuktikan dengan tingginya tingkat penjualan dan akan berdampak kepada kinerja dan keuntungan organisasi yang menjadi lebih baik, sehingga memungkinkan untuk mendapatkan promosi atau kenaikan jabatan.

Karakteristik pelatihan responden, dari 22 responden yang diteliti terdapat 5 responden $(22,7 \%)$ dengan pelatihan 0 kali, 12 responden $(54,5 \%)$ dengan pelatihan 1 - 2 kali, dan 5 responden $(22,7 \%)$ dengan pelatihan $3-4$ kali. Pelatihan adalah suatu bentuk infestasi jangka panjang dimaksudkan untuk membantu meningkatkan kemampuan para pegawai dalam melaksanakan tugas (Siagian, 1996).

Karakteristik

pengetahuan responden, dari 22 responden yang diteliti terdapat 12 responden $(54,5 \%)$ memiliki pengetahuan cukup, 10 responden $(45,5 \%)$ dengan pengetahuan baik dan tidak ada responden yang memiliki pengetahuan kurang. Sebagian besar $(54,5 \%)$ perawat memiliki pengetahuan cukup. Pengetahuan responden tentang penatalaksanaan pasien Dekompensasi Kordis juga ditemukan kategori cukup, hal ini disebabkan perawat yang bekerja di ruang ICVCU RSUD Dr. Moewardi Surakarta mempunyai latar belakang pendidikan, dan lama bekerja yang berbeda-beda serta minimnya pengalaman. Pengetahuan adalah hasil penginderaan manusia, atau hasil tahu seseorang terhadap objek melalui indera yang dimilikinya. Pengetahuan merupakan domain yang sangat penting untuk terbentuknya tindakan seseorang. Dari pengalaman dan penelitian, ternyata perilaku yang didasari pengetahuan akan lebih langgeng dari pada perilaku yang tidak didasari pengetahuan (Notoatmodjo, 2005).

2. Hubungan antara umur dengan pengetahuan perawat tentang penatalaksanaan asuhan keperawatan pasien Dekompensasi Kordis.

Berdasarkan hasil perhitungan uji statistik menunjukkan bahwa tidak ada hubungan antara umur dengan pengetahuan perawat tentang penatalaksanaan asuhan keperawatan pasien Dekompensasi Kordis. Hal ini dibuktikan dari uji statistik yang diperoleh perbandingan nilai $\mathrm{r}$ hitung Rank Spearmant sebesar 0,082 , nilai $\mathrm{r}$ tabel 
dengan $\mathrm{N}=22$ dan taraf signifikan 0,05 sebesar 0,428 . Karena $\mathrm{r}$ hitung $<\mathrm{r}$ tabel $(0,082<0,428)$ maka hipotesis Ho diterima dan Ha ditolak.

Hasil di atas tidak sejalan dengan teori yang dikemukakan oleh Suliha (2002) bahwa umur mempengaruhi terhadap daya tangkap dan pola pikir seseorang. Semakin bertambah umur akan semakin berkembang pula daya tangkap, pola pikir, kemampuan intelektual, motorik, pemecahan masalah dan kemampuan verbalnya. Sebaliknya menjelang usia lanjut atau pada umur tertentu kemampuan penerimaan atau mengingat suatu pengetahuan dan perkembangan mental tidak secepat ketika berumur belasan tahun (Suliha, 2002). Penelitian ini juga tidak sesuai dengan pendapat Gibson, dkk, (1997) yang menyatakan bahwa pada umur $40-54$ tahun merupakan tahap perawatan, yang ditandai dengan usaha untuk stabilisasi dari hasil usaha masa lampau. Pada tahap ini seseorang akan memerlukan penghargaan, tetapi banyak juga yang mempunyai pengalaman kritis dimana kesehatan mulai memburuk dan rasa khawatir yang tinggi dan tidak membutuhkan lagi peningkatan karir dan akibatnya prestasi kerja menurun. Hal ini menjelaskan bahwa tindakan dan pengetahuan perawat tidak tergantung pada kekuatan fisik dan kesehatan seseorang yang dipengaruhi umurnya. Pengetahuan perawat dalam penatalaksanaan asuhan keperawatan pasien Dekompensasi Kordis merupakan kewajiban yang dilaksanakan berdasarkan standar prosedur yang telah ditetapkan.

3. Hubungan antara tingkat pendidikan dengan pengetahuan perawat tentang penatalaksanaan asuhan keperawatan pasien Dekompensasi Kordis
Berdasarkan hasil perhitungan uji statistik menunjukkan bahwa tidak ada hubungan antara tingkat pendidikan dengan pengetahuan perawat tentang penatalaksanaan asuhan keperawatan pasien Dekompensasi Kordis. Hal ini dibuktikan dari uji statistik yang diperoleh perbandingan nilai $\mathrm{r}$ hitung Rank Spearmant sebesar 0,290, nilai $r$ tabel dengan $\mathrm{N}=22$ dan taraf signifikan 0,05 sebesar 0,428 . Karena $r$ hitung $<\mathrm{r}$ tabel $(0,290<0,428)$ maka hipotesis Ho diterima dan Ha ditolak.

$\begin{array}{crr}\text { Dilihat dari latar belakang } \\ \text { pendidikan, } & \text { responden } & \text { yang }\end{array}$
berpendidikan SPK masih ada yaitu sebanyak 2 responden, namun saat ini pendidikan SPK sudah tidak ada lagi di Indonesia dan digantikan dengan jenjang pendidikan diploma tiga sehingga dua responden tersebut sekarang dalam proses pendidikan S1. Berdasarkan wawancara yang dilakukan oleh peneliti terhadap kepala ruang, meskipun tingkat pendidikan perawat hanya SPK namun pengetahuannya tidak kalah dengan yang tingkat pendidikannya S1 Keperawatan karena perawat tersebut sedang menjalani pendidikan S1dan juga pernah mengikuti pelatihan. Pengetahuan responden juga sebagian besar tergolong cukup. Akan tetapi peningkatan pengetahuan ini tidak mutlak disebabkan karena pendidikan formal saja, tetapi bisa disebabkan karena faktor-faktor lain yang berhubungan dengan pengetahuan. Sebagaimana disampaikan oleh Notoatmodjo (2007) yang menjelaskan bahwa pengetahuan berhubungan dengan banyak faktor, meliputi faktor internal, seperti kesehatan, intelegensi, perhatian, minat dan faktor eksternal seperti keluarga, metode pembelajaran, masyarakat. Selain itu pengetahuan ini juga bisa berhubungan 
dengan tingkat pendidikan, informasi, budaya, pengalaman, dan sosial ekonomi (Suliha, 2002). Umur dan pekerjaan juga bisa berhubungan dengan pengetahuan, sebagaimana disampaikan oleh Asrofudin (2010). Sehingga belum berarti seseorang yang berpengetahuan tinggi mutlak berpendidikan tinggi pula, karena banyak faktor yang berhubungan dengan pengetahuan seseorang tersebut.

4. Hubungan antara lama kerja dengan penatalaksanaan asuhan keperawatan pasien Dekompensasi Kordis.

Berdasarkan hasil perhitungan uji statistik menunjukkan bahwa tidak ada hubungan antara lama kerja dengan pengetahuan perawat tentang penatalaksanaan asuhan keperawatan pasien Dekompensasi Kordis. Hal ini dibuktikan dari uji statistik yang diperoleh perbandingan nilai $\mathrm{r}$ hitung Rank Spearmant sebesar 0,254, nilai $r$ tabel dengan $\mathrm{N}=22$ dan taraf signifikan 0,05 sebesar 0,428 . Karena $r$ hitung $<\mathrm{r}$ tabel $(0,254<0,428)$ maka hipotesis Ho diterima dan $\mathrm{Ha}$ ditolak. Untuk menunjukkan kuat rendahnya hubungan antara lama kerja dengan pengetahuan perawat tentang penatalaksanaan asuhan keperawatan pasien Dekompensasi Kordis di ruang ICVCU Surakarta Tahun 2011 dapat dilihat dalam interpretasi koefisien korelasi menurut Sugiyono (2007) dengan $r$ hitung sebesar 0,254 maka menunjukkan bahwa tidak ada hubungan antara lama kerja dengan pengetahuan perawat tentang penatalaksanaan asuhan keperawatan pasien Dekompensasi Kordis di ruang ICVCU Surakarta Tahun 2011 termasuk kategori rendah.

Menurut Gibson, dkk (1997), masa kerja seseorang akan menentukan prestasi individu yang merupakan dasar prestasi dan kinerja organisasi. Semakin lama seseorang bekerja di suatu organisasi, maka tingkat prestasi individu akan semakin meningkat yang dibuktikan dengan tingginya tingkat penjualan dan akan berdampak kepada kinerja dan keuntungan organisasi yang menjadi lebih baik, sehingga memungkinkan untuk mendapatkan promosi atau kenaikan jabatan.

Dilihat dari lama kerja, sebagian besar responden mempunyai lama kerja $<5$ tahun dan sebagian responden lama kerjanya $>10$ tahun. Sedangkan untuk pengetahuan responden hasilnya tidak begitu jauh, responden dengan pengetahuan cukup sebanyak 12 responden dan responden yang pengetahuannya baik 10 responden. Akan tetapi peningkatan pengetahuan ini tidak mutlak disebabkan karena lama kerja saja, tetapi bisa disebabkan karena faktor-faktor lain yang berhubungan dengan pengetahuan. Sebagaimana disampaikan oleh Notoatmodjo (2007) yang menjelaskan bahwa pengetahuan berhubungan dengan banyak faktor, meliputi faktor internal, seperti kesehatan, intelegensi, perhatian, minat dan faktor eksternal seperti keluarga, metode pembelajaran, masyarakat. Sehingga belum berarti seseorang yang berpengetahuan tinggi mutlak mempunyai masa kerja yang lama, karena banyak faktor yang berhubungan dengan pengetahuan seseorang tersebut, tidak hanya masa kerja.

5. Hubungan antara pelatihan perawat dengan pengetahuan perawat tentang penatalaksanaan asuhan keperawatan pasien Dekompensasi Kordis.

Berdasarkan hasil perhitungan uji statistik menunjukkan bahwa ada hubungan antara pelatihan dengan pengetahuan perawat tentang 
penatalaksanaan asuhan keperawatan pasien Dekompensasi Kordis. Hal ini dibuktikan dari uji statistik yang diperoleh perbandingan nilai $\mathrm{r}$ hitung Rank Spearmant sebesar 0,542 , nilai $\mathrm{r}$ tabel dengan $\mathrm{N}=22$ dan taraf signifikan 0,05 sebesar 0,428 . Karena $\mathrm{r}$ hitung $>\mathrm{r}$ tabel $(0,542>0,428)$ maka hipotesis Ho ditolak dan Ha diterima. Untuk menunjukkan kuat rendahnya hubungan antara pelatihan dengan pengetahuan perawat tentang penatalaksanaan asuhan keperawatan pasien Dekompensasi Kordis di ruang ICVCU Surakarta Tahun 2011 dapat dilihat dalam interpretasi koefisien korelasi menurut Sugiyono (2007) pada tabel 9, dengan $\mathrm{r}$ hitung sebesar 0,542 maka menunjukkan bahwa ada hubungan antara pelatihan dengan pengetahuan perawat tentang penatalaksanaan asuhan keperawatan pasien Dekompensasi Kordis di ruang ICVCU Surakarta Tahun 2011 termasuk kategori sedang.

\section{KESIMPULAN DAN SARAN}

1. Tidak ada hubungan antara umur dengan pengetahuan perawat tentang penatalaksanaan asuhan keperawatan pasien Dekompensasi Kordis RSUD Dr. Moewardi

2. Tidak ada hubungan antara tingkat pendidikan dengan pengetahuan perawat tentang penatalaksanaan asuhan keperawatan pasien Dekompensasi Kordis RSUD Dr. Moewardi

3. Tidak ada hubungan antara lama kerja dengan pengetahuan perawat tentang penatalaksanaan asuhan keperawatan pasien Dekompensasi Kordis RSUD Dr. Moewardi

4. Ada hubungan antara pelatihan dengan pengetahuan perawat tentang penatalaksanaan asuhan keperawatan pasien Dekompensasi Kordis RSUD Dr. Moewardi

\section{DAFTAR RUJUKAN}

Arikunto, S. (2006). Prosedur Penelitian Suatu Pendekatan Praktek Cetakan Ketigabelas.Jakarta:Rineka Cipta

Asrofudin. (2010). Faktot-Faktor yang Mempengaruhi Pengetahuan. Oktober 29, 2010. http://www.canboyz.co.cc

Black. J. M. \& Jacob E. M. (1993). Lucman and Surensen, Medical Surgical Nursing: a Psycophisologi Approach 4th ed. W. B. Saunders, Philadelphia

Brunner \& Suddarth. (2001). Buku Ajar Keperawatan Medikal-Bedah Edisi 8. Jakarta: EGC

Depkes RI. (1998). Standart Tenaga Keperawatan Di Rumah Sakit (Cetakan Pertama). Jakarta: Depkes

Doenges M.E, Moorhouse, M.F. \& Geissler, A.C. (1999). Rencana Asuhan Keperawatan, Pedoman untuk Perencanaan dan Pendokumentasian Perawatan Pasien, Edisi 3. Jakarta : EGC

Gibson, JK.et al. (1997). Perilaku Struktur Proses Jilid 1Edisi ke-8. Jakarta: Bina Aksara Rupa

Hastono, S.P. (2007). Analisa Data Kesehatan. Jakarta:Fakultas Kesehatan Masyarakat Universitas Indonesia

Hudak, C.M \& Gallo, B.M. (1997). Keperawatan Kritis:Pendekatan Holistik, Edisi 6, Vol.1. Jakarta:EGC

Mandey,FC. (2004). Pengetahuan.http:www.hayati.leb. com, rudy et/manday, htm, Alk.Akses tanggal 11 Mei 2009 
Mansjoer, A. (2001). Kapita Selekta Kedokteran Edisi Ketiga. Jakarta : Media Aescapileus

Maryoto, J. (2009). Dekompensatio Cordis.

http://idmgarut.wordprees.com/wp -comments-post.php, di peroleh tanggal 4 Maret 2010

Nurachmah, E. (2000). Legislasi Keperawatan. Makalah Seminar Sehari PSIK UGM Yogyakarta

Nursalam. (2008). Konsep \& Penerapan Metodologi Penelitian Ilmu Keperawatan Edisi 2. Jakarta : Salemba Medika

Price S.A \& Wilson, L.M. (1994). Patofisiologi, Konsep Klinis Proses-Proses Penyakit, Edisi 4, Buku 1. Jakarta : EGC

Purwanto, H. 2005. Pengantar Perilaku Manusia. Jakarta: EGC

Purwanto, Ngalim. (2000).Psikologi Pendidikan.Bandung: PT Remaja Rosda karya
Robbin, S. (2001). Perilaku Organisasi. Jakarta. PT INDEKS Kelompok GRAMEDIA

Siagian, Sondong P. (1996). Management Sumber Daya Manusia. Jakarta : Bumi Aksara

Sugeng, J. I \& Sitompul Barito. (2004). Buku ajar kardiologi, edisi kelima. FKUI : Jakarta

Sugiyono. (2007). Statistik untuk Penelitian. Bandung. Alfabeta

Suliha, U. (2002). Pendidikan Kesehatan Dalam Keperawatan.Jakarta:EGC

Sunaryo. (2004). Psikologi Untuk Keperawatan. Jakarta:EGC

Tabrani. (1998). Agenda Gawat Darurat Jilid 2. Bandung : Alumni Bandung

Tucker, S.M. (1998). Standar Perawatan Pasien. Jakarta : EGC

Wasis. (2008). Pedoman Riset Praktis Untuk Profesi Perawat. Jakarta: EGC 